\title{
Pengaruh Soil Water Characteristic Curve (SWCC) pada Pemodelan Tanggul yang Menggunakan Material Campuran Lumpur Sidoarjo (Lusi) dan Tanah Lempung
}

\author{
Indra Rahma Hardiana ${ }^{1}{ }^{, *}$, Ria Asih Aryani Soemitro ${ }^{1}$, Indarto ${ }^{1}$, Trihanyndio Rendy Satrya ${ }^{1}$ \\ Departemen Teknik Sipil, Institut Teknologi Sepuluh Nopember, Surabaya \\ Koresponden*, Email: indrarahmahardiana@yahoo.co.id
}

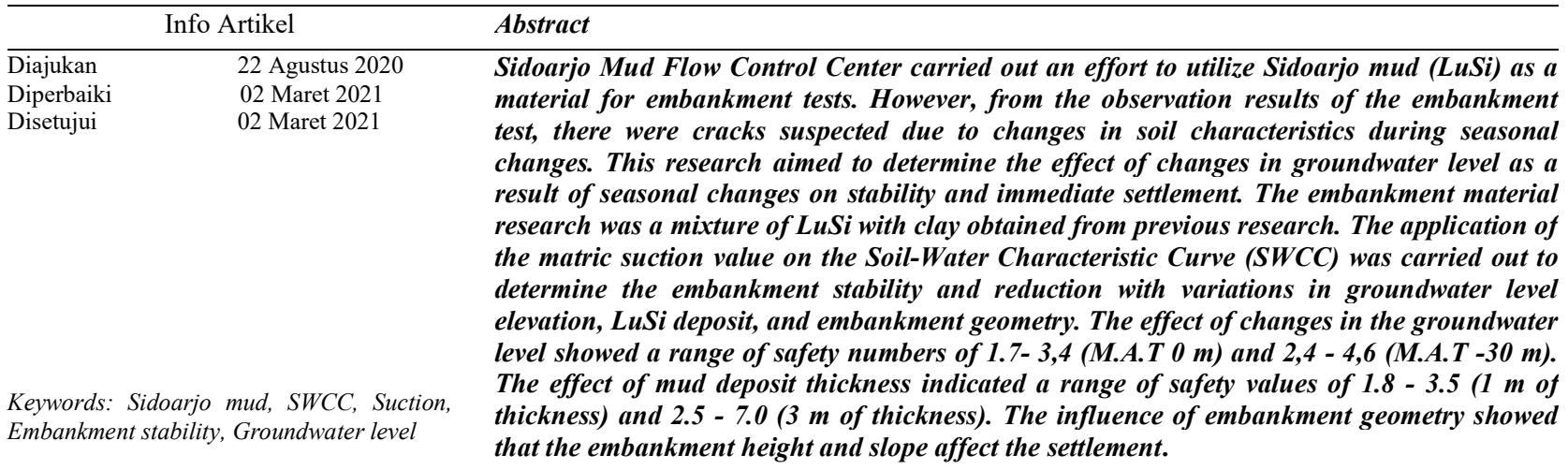

Abstrak

Pusat Pengendalian Lumpur Sidoarjo melakukan usaha pemanfaatan Lumpur Sidoarjo (LuSi) sebagai bahan material tanggul uji. Namun, dari hasil pengamatan tanggul uji, terdapat retakan yang ditengarai akibat perubahan karakteristik tanah saat perubahan musim. Penelitian ini bertujuan untuk mengetahui pengaruh perubahan muka air tanah sebagai akibat perubahan musim terhadap kestabilan dan penurunan segera pada tanggul. Material tanggul yang diteliti adalah campuran LuSi dengan tanah lempung yang didapatkan dari penelitian terdahulu. Penerapan nilai matric suction pada SoilWater Characteristic Curve (SWCC) dilakukan untuk mengetahui kestabilan serta penurunan tanggul dengan variasi elevasi muka air tanah, endapan LuSi dan geometri tanggul. Pengaruh perubahan muka air tanah (M.A.T.) menunjukkan rentang angka keamanan 1,7- 3,4 (M.A.T. 0 m) dan 2,4 - 4,6 (M.A.T. -30 m). Pengaruh tebal endapan lumpur menunjukkan rentang angka keamanan 1,8 - 3,5 (tebal $1 \mathrm{~m}$ ) dan 2,5 - 7,0 (tebal 3

Kata kunci: Lumpur Sidoarjo, SWCC, Suction, Kestabilan Tanggul, Pengaruh Muka Air Tanah m). Pengaruh geometri tanggul menunjukkan bahwa ketinggian dan kemiringan tanggul berpengaruh terhadap penurunan.

\section{Pendahuluan}

Luapan lumpur Sidoarjo muncul sejak tanggal 29 Mei 2006 sampai saat ini. Untuk mengatasi luapan tersebut, Pemerintah membuat tanggul penahan lumpur. Namun, hingga saat ini, lebih dari 10 kali tanggul penahan luapan lumpur Sidoarjo runtuh. Pusat Pengendalian Lumpur Sidoarjo (PPLS) membuat tanggul baru yang lebih stabil sebagai solusi [3].

Berdasarkan penerapan penelitian tanggul uji pada tahun 2018, PPLS melakukan observasi dan evaluasi kinerja dari tanggul uji pada tahun 2019 [3]. Berdasarkan pengamatan yang dilakukan, terdapat retakan pada tanggul uji yang ditengarai sebagai akibat adanya perubahan karakteristik tanah saat terjadinya perubahan musim dan juga sebagai akibat dari campuran material kurang memenuhi persyaratan sebagai material timbunan. Apabila perubahan musim terjadi secara terus-menerus, maka akan mengubah sifat kondisi tanah, baik secara fisis maupun mekanis.

Kondisi perubahan musim menjadi penyebab peristiwa keretakan dan beberapa sisi tanggul mengalami kelongsoran. Kondisi ini biasanya terjadi pada akhir musim hujan. Kuwano dan Chen menyampaikan kelongsoran yang terjadi tidak hanya disebabkan naiknya tegangan air pori seiring dengan naiknya permukaan air tanah, tetapi juga oleh berkurangnya kekuatan geser tanah akibat naiknya derajat kejenuhan tanah atau berkurangnya suction tanah [7]

Hal tersebut yang melatarbelakangi bahwa pengaruh SWCC (Soil-Water Characteristic Curve) atau pengaruh 
suction perlu diteliti untuk mengetahui dampaknya terhadap kestabilan tanggul.

Pada tahun 2018 Pusat Pengendalian Lumpur Sidoarjo (PPLS) melakukan penelitian pemanfaatan Lumpur Sidoarjo (LuSi) untuk material tanggul uji dan didapatkan campuran optimal campuran 70\% (LuSi) dengan 30\% (Tanah Galian Pasuruan) [5]. Data penelitian tersebut belum dilengkapi data SWCC dan beberapa parameter masih dalam proses uji laboratorium. Berkaitan dengan hal tersebut, maka dicari padanan data penelitian yang menyerupai campuran hasil penelitian PPLS. Berdasarkan hasil pemetaan data penelitian terdahulu dari sumber yang berbeda didapatkan campuran optimum yaitu $20 \%$ LuSi dan $80 \%$ tanah lempung Kertajaya [5].

Pada penelitian ini menggunakan pemodelan analisa numerik menggunakan data Soil-Water Characteristic Curve (SWCC) yang didapatkan dari hasil pendekatan sifat fisis dan mekanis.

Perolehan Data SWCC yang didapatkan dari tanah Pulau Dalam, Malaysia menggunakan metode penelitian laboratorium yaitu metode tidak langsung (Indirect method) dengan mengambil data hasil pengujian Triaxial pada kondisi consolidated undrained (CU) [6].

Penelitian ini bertujuan untuk mengetahui pengaruh perubahan muka air tanah akibat pengaruh nilai suction terhadap analisa numerik kestabilan, rembesan, dan penurunan segera tanggul penahan lumpur. Adapun material penyusun tanggul tanah dasar adalah menggunakan data hasil uji bor log dalam DB - 01[3]. Data tanah material penyusun tanggul menggunakan data penelitian dengan komposisi campuran yang terdiri dari LuSi (20\%) yang dicampur dengan tanah lempung Kertajaya Indah (80\%) [5].

\section{Metode}

Metode penelitian terbagi menjadi beberapa tahapan. Metode penelitian dimulai dengan analisa studi literatur penelitian terdahulu. Hasil dari analisa tersebut kemudian dilakukan pemetaan data sekunder. Penggunaan data sekunder hasil pemetaan dari penelitian terdahulu ini dilakukan karena tidak dapat diadakannya penelitian di laboratorium pada masa pandemi Covid-19.

Tahap selanjutnya yaitu melakukan tahap pemetaan data sekunder untuk nilai dari Soil Water Characteristic Curve (SWCC). Hasil pemetaan data sekunder dilakukan dengan mengidentifikasi nilai Spesifikasi Timbunan Biasa dengan syarat peraturan Pekerjaan Umum dan Perumahan Rakyat Modul-4 Spesifikasi Pekerjaan Tanah 2016 [2]. Pemeriksaan dilakukan untuk menunjang tanggul yang dimodelkan sesuai dengan spesifikasi peraturan timbunan biasa.
Tahap akhir penelitian ini menitik beratkan pengaruh nilai suction atau Soil Water Characteristic Curve (SWCC) pada konfigurasi geometri tanggul terhadap variasi muka air tanah dan variasi endapan lumpur dengan metode numerik yang menggunakan program bantu analisa numerik stabilitas, analisa numerik rembesan, dan analisa numerik penurunan segera pada tanggul penahan lumpur. Selanjutnya, dilakukan analisa hasil pemodelan, pembahasan, dan penarikan kesimpulan.

Penjabaran dari metode penelitian sebagai berikut:

\section{Data Sekunder}

Data sekunder diperoleh dari penelitian terdahulu. Penggunaan data sekunder dari penelitian terdahulu ini bertujuan karena tidak dapat diadakannya penelitian di laboratorium pada masa pandemi Covid-19. Data yang digunakan untuk perencanaan ini adalah data sekunder, meliputi:

1. Parameter Data Tanah Dasar

Parameter tanah dasar di bawah tanggul menggunakan data bor dalam milik PPLS yang dilakukan disekitar tanggul yaitu data Borlog DB-01 yang ditunjukan pada Gambar 1 [3]. Data parameter tanah dasar digunakan untuk program bantu analisa numerik program rembesan.

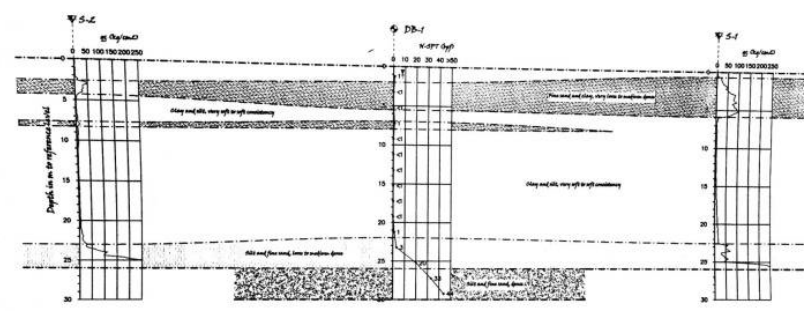

Gambar 1. Penampang Tanah Dasar Tanggul [3]

2. Parameter Data Tanah Penyusun Tanggul

Data sekunder penyusun tanggul didapatkan dari pemetaan data penelitian terdahulu yaitu campuran 70\% Lumpur Sidoarjo dan 30\% Tanah Galian Pasuruan[3]. Tetapi, penggunaan data campuran 70\% LuSi dan 30\% Tanah Galian Pasuruan [3] sebagai data acuan data sekunder tidak lengkap untuk beberapa parameter fisis dan mekanis.

Penelitian ini menggunakan data sekunder yang memiliki karakteristik padanan yang sama yaitu didapatkan material data tanah untuk campuran optimum 20\% LuSi dan $80 \%$ tanah lempung Kertajaya [5].

Untuk data tanah campuran optimum 20\% LuSi dan $80 \%$ tanah lempung Kertajaya belum memiliki data SWCC, untuk melengkapi data tersebut maka menggunakan data SWCC dari data Penelitian Tanah Dalam, Malaysia [6]. 


\section{Identifikasi Campuran LuSi dan Tanah Lempung terha- dap Nilai Spesifikasi Timbunan Biasa}

Untuk mengidentifikasi data sekunder lumpur Sidoarjo dan tanah lempung Kertajaya dengan melakukan pemeriksaan nilai spesifikasi timbunan biasa dengan SNI pada campuran LuSi dan tanah lempung untuk menunjang tanggul yang dimodelkan sesuai dengan syarat peraturan Pekerjaan Umum dan Perumahan Rakyat Modul-4 Spesifikasi Pekerjaan Tanah [2].

Pada pemetaan data dilakukan pula pemeriksaan nilai spesifikasi timbunan biasa dengan SNI untuk mengetahui timbunan yang memenuhi persyaratan timbunan biasa.

Menurut Peraturan timbunan biasa, PUPR syarat timbunan biasa sebagai berikut [2]:

1. Bahan yang dipilih sebaiknya tidak termasuk tanah yang berplastisitas tinggi, yang diklasifikasikan sebagai A-7-6 menurut AASHTO M145 atau sebagai $\mathrm{CH}$ menurut Unified Soil Classification System (USCS).

2. Bila penggunaan tanah yang berplastisitas tinggi tidak dapat dihindarkan, bahan tersebut harus digunakan hanya pada bagian dasar dari timbunan atau pada penimbunan kembali yang tidak memerlukan daya dukung atau kekuatan geser yang tinggi.

3. Bahan timbunan bila diuji dengan SNI 03-1744-1989, harus memiliki CBR tidak kurang dari $6 \%$ setelah perendaman 4 hari bila dipadatkan $100 \%$ kepadatan kering maksimum (MDD) seperti yang ditentukan oleh SNI 03-17421989.

4. Tanah sangat ekspansif yang memiliki nilai aktif lebih besar dari 1,25 atau derajat pengembangan yang diklasifikasikan oleh AASHTO T258 sebagai "very high" atau "extra high", tidak boleh digunakan sebagai bahan timbunan.

5. Nilai aktif adalah perbandingan antara Indeks Plastisitas/PI-(SNI 03-19661989) dan persentase kadar lempung (SNI 03-3422-1994).

Persyaratan timbunan tersebut digunakan untuk mengklasifikasi data sekunder yang mendekati campuran LuSi dan tanah lempung untuk kemudian divalidasi memenuhi spesifikasi timbunan biasa atau tidak memenuhi spesifikasi. Tujuan validasi spesifikasi timbunan agar timbunan dapat berfungsi optimum sesuai dengan kegunaan timbunan yang akan direncanakan.

\section{Pemetaan Data Sekunder terhadap Soil-Water Charac- teristic Curve (SWCC)}

Pada data sekunder penyusun tanggul yang terpilih yaitu data tanah campuran optimum 20\% LuSi dan $80 \%$ tanah lempung Kertajaya belum memiliki data SWCC. Pada tahap ini dilanjutkan dengan pemetaan data SWCC. Hal tersebut dilakukan karena tidak semua data sekunder mencantumkan nilai dari SWCC.

Data SWCC digunakan sebagai parameter untuk analisa numerik rembesan serta untuk mengetahui pengaruh nilai suction terhadap faktor keamanan tanggul. Metode yang dilakukan dalam pemetaan data yaitu dengan melihat nilai parameter fisik dan mekanis tanah yang mendekati data sekunder campuran optimum campuran optimum (LuSi dan tanah lempung Kertajaya Indah Surabaya)[5]. Dari hasil metode pemetaan didapatkan data SWCC dari tanah Pulau Dalam, Malaysia. Pada Tabel 1 menjelaskan tentang data SWCC (Soil-Water Characteristic Curve) yang diambil dari data tanah dengan tanah Pulau Dalam, Malaysia [6]. Berdasarkan Tabel 1, suction maksimum terjadi ketika volumetric water content (VWC) berada pada titik minimum yaitu ketika butir tanah memiliki rongga yang cukup untuk menyerap air.

Tabel 1. Data SWCC Plot Tanah Pantai Dalam, Malaysia [6]

\begin{tabular}{cc}
\hline $\begin{array}{c}\text { Vol. Water Content } \\
\mathrm{m}^{3} / \mathrm{m}^{3}\end{array}$ & $\begin{array}{c}\text { Matric Suction } \\
\mathrm{KPa}\end{array}$ \\
\hline 0,329 & 1 \\
0,327 & 10 \\
0,3099 & 20 \\
0,298 & 30 \\
0,288 & 40 \\
0,27 & 50 \\
0,25 & 90 \\
0,225 & 200 \\
0,2 & 300 \\
0,19 & 400 \\
\hline
\end{tabular}

Penelitian SWCC tentang tanah Pulau Dalam, Malaysia menggunakan metode pressure plate extractor dengan kapasitas $1500 \mathrm{kN} / \mathrm{m}^{2}$ mengacu pada ASTM D6836-02[6]. Data tanah Pulau Dalam, Malaysia dalam penelitian ini menurut klasifikasi berplastisitas rendah, dengan nilai Indeks Plastisitas (10\%). Pengklasifikasian tanah menurut analisa saringan yaitu Kerikil (18\%), Pasir (46\%), Lanau (26\%), Lempung (10\%), Batas Cair (27), Batas Plastis (17\%), dan Spesifikasi Gravity (Gs) senilai 2,62 [6].

\section{Pemeriksaan Nilai Suction Pemodelan Tanggul Pada Kurva SWCC}

Pemeriksaan nilai suction bertujuan untuk mengetahui pengaruh nilai suction pada pemodelan tanggul. Pemeriksaan ini juga dilakukan dengan cara menyelesaikan analisis 
stabilitas lereng dengan menggunakan program analisa numerik dan selanjutnya dibandingkan dengan hasil dari analisis stabilitas lereng secara teoritis dilihat dari data kurva SWCC (Soil-Water Characteristic Curve).

Menurut Indarto besarnya hisapan dari grafik yang dinyatakan dalam angka $\mathrm{pF}$, bila dinyatakan dalam tegangan air pori negatif maka nilai tersebut harus dikonversikan kedalam $\mathrm{kPa}$ atau $\mathrm{kg} / \mathrm{cm}^{2}[1]$.

Berdasarkan hasil pemeriksaan nilai suction pada pemodelan tanggul dengan menggunakan grafik SWCC dari data sekunder [6] (Gambar 2), maka didapatkan nilai suction. Berdasarkan grafik di bawah, titik $\mathrm{C}$ yaitu posisi suction = $30 \mathrm{Kpa}=0,3 \mathrm{Bar}=300 \mathrm{~cm}=3$ meter. Hasil penerapan (Validasi Suction) pada Gambar 2 menunjukkan perihal pemeriksaan pengaruh suction atau tegangan air pori negatif terhadap tanggul dari hasil pemeriksaan posisi suction. Nilai suction tersebut didapatkan hasil bahwa pemodelan telah sesuai kurva grafik kurva $S W C C$.

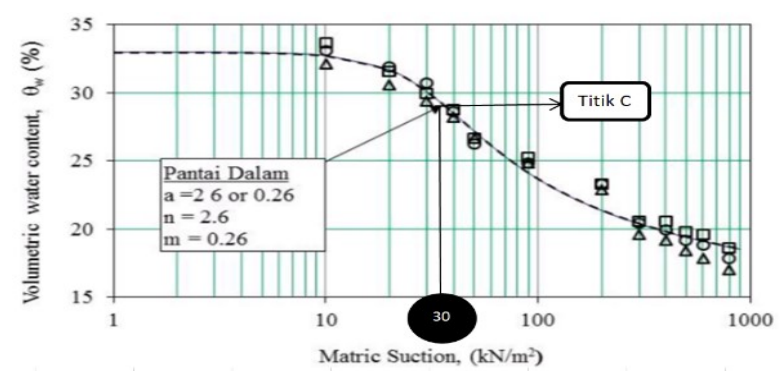

Gambar 2. SWCC dari Tanah Pulau Dalam [6]

\section{Parameter Pemodelan Tanggul dengan Penerapan $S W$ - CC (Pemeriksaan Nilai Suction) pada Program Bantu Analisa Numerik}

Pada penelitian ini dilakukan analisa numerik dengan pemodelan tanggul yang mencakup analisa perubahan nilai faktor keamanan yang terjadi pada tanggul akibat beberapa variasi pemodelan tanggul yaitu: variasi kemiringan tanggul, variasi ketinggian tanggul, variasi muka air tanah pada tanggul, variasi endapan lumpur.

\section{Geometri Tanggul}

Geometri pemodelan tanggul meninjau tehadap perubahan nilai faktor keamanan akibat variasi muka air tanah pada saat muka air tanah (M.A.T) 0 meter dan -30 meter dengan variasi kemiringan yaitu 1:1, 1:1,5, dan 2 serta ketinggian $3 \mathrm{~m}, 5 \mathrm{~m}$, dan $7 \mathrm{~m}$. Sedangkan untuk variasi endapan lumpur dengan konfigurasi geometri dengan tebal endapan lumpur yaitu $1 \mathrm{~m}, 2 \mathrm{~m}$, dan $3 \mathrm{~m}$ menggunakan variasi muka air tanah $0 \mathrm{~m}$.
Pemodelan tanggul menggunakan program bantu analisa numerik stabilitas dan analisa numerik rembesan. Penelitian ini juga bertujuan untuk mencari besarnya penurunan segera dengan menggunakan analisa numerik penurunan segera.

Berbeda dengan pemodelan analisa numerik rembesan dilakukan dengan memasukkan data dari $S W C C$, yang meliputi karakteristik tanah penyusun tanggul serta fungsi hydraulic conductivity dan volumetric water content.

1. Parameter Data Tanah Dasar Untuk Pemodelan Timbunan Tanggul

Data tanah dasar menggunaakan data sekunder dari asumsi data penelitian hasil uji bor log dalam DB-01 [3]. Tabel 2 merupakan data tanah yang digunakan untuk parameter material menggunakan analisa numerik. Pada pemodelan tanggul menggunakan nilai suction dengan tahapan awal yaitu analisa numerik untuk rembesan, material model yaitu saturated only, parameter tanah dasar seperti pada Tabel 2 untuk 6 lapisan tanah dengan jenis tanah berbeda.

Pada lapisan 1 jenis tanah yaitu lempung dan lanau nilai saturated conductivity adalah $1,00 \mathrm{E}-08 \mathrm{~m} / \mathrm{sec}$, untuk lapisan 2 kedalaman yaitu pasir untuk nilai saturated conductivity adalah $0,0001 \mathrm{~m} / \mathrm{sec}$, lapisan 3 jenis tanah yaitu lempung lanau untuk nilai saturated conductivity adalah 1,00E-08 m/sec. Lapisan 4 jenis tanah yaitu lempung lanau untuk nilai saturated conductivity adalah 1,00E-08 m/se. Lapisan 5 jenis tanah yaitu lanau dan pasir. Nilai saturated conductivity untuk lapisan 5 adalah 1,00E-05 m/sec. Lapisan 6 pada kedalaman jenis tanah yaitu lanau dan pasir dari parameter yang berbeda dan kedalaman tanah dasar yaitu 30 meter [3]. Saturated volume water untuk semua lapisan yaitu $0 \mathrm{~m}^{2} / \mathrm{m}^{2}$ dan besar nilai Mv yaitu $0 \mathrm{kPa}$.

2. Parameter Data Penyusun Tanggul Pada Pemodelan Timbunan Tanggul.

Material yang digunakan untuk data tanah penyusun tanggul menggunakan data tanah dengan campuran $20 \%$ LuSi dan 80\% Tanah Kertajaya Surabaya [5].

Tahap setelah memasukkan nilai parameter untuk data tanah dasar (Tabel 2) yaitu melanjutkan dengan memasukkan data timbunan tanggul pada pemodelan program numerik dengan Tabel 3 dan Tabel 4. Pada pemodelan analisa numerik rembesan yang dimasukkan pada parameter data tanah timbunan pada pemodelan program bantu. Nilai residual, minimal, dan maksimal suction didapatkan dari data sekunder campuran optimum. Tabel 4 adalah data hydraulic conductivity function yang akan dimasukkan pada parameter data tanah timbunan pada pemodelan analisa numerik stabilitas. Analisa yang didapatkan untuk nilai minimal 
suction dan maksimal suction didapatkan dari data SWCC Pulau dalam [6].

Tabel 3. Input Data Timbunan untuk Volume Water Content Pada Pemodelan Analisa Numerik untuk Stabilitas

\begin{tabular}{lccc}
\hline Parameter & $\begin{array}{c}\text { Estimate } \\
\text { Vol. water }\end{array}$ & $\begin{array}{c}\text { Konsentrasi } \\
(\%)\end{array}$ & Keterangan \\
\hline $\begin{array}{l}\text { Sat. Vol } \\
\text { Water }\end{array}$ & $\mathrm{m}^{2} / \mathrm{m}$ & 0,15 & \\
$\begin{array}{l}\text { Content } \\
\text { Sample }\end{array}$ & - & Clay & \\
Material & & & \\
$\begin{array}{l}\text { Min. Suction } \\
\text { Max. }\end{array}$ & $\mathrm{kPa}$ & 1 & Sesuai data \\
$\begin{array}{l}\text { Suction. } \\
\text { Saturated X- }\end{array}$ & $\mathrm{m} / \mathrm{sec}$ & $1,00 \mathrm{E}-07$ & Korelasi \\
$\begin{array}{l}\text { Conductivity } \\
\text { Mv }\end{array}$ & & 400 & \\
Ky'Ratio & $\mathrm{kPa}$ & 0 & Korelasi \\
Kx'Ratio & & 1 & \\
\hline
\end{tabular}

Tabel 4. Data Tanah Timbunan untuk Pemodelan Analisa Numerik Rembesan

\begin{tabular}{|c|c|c|}
\hline Parameter & $\begin{array}{c}\text { Estimate Vol. } \\
\text { water }\end{array}$ & $\begin{array}{c}\text { Konsentrasi } \\
(\%)\end{array}$ \\
\hline Vol Water Content & $\mathrm{m}^{2} / \mathrm{m}^{2}$ & Clay W/C \\
\hline Sample Material & & Function \\
\hline Saturated Kx & $\mathrm{m} / \mathrm{sec}$ & $1,00 \mathrm{E}-07$ \\
\hline $\begin{array}{l}\text { Residual water } \\
\text { content }\end{array}$ & $\mathrm{m}^{2} / \mathrm{m}^{2}$ & 0,30 \\
\hline Min suction & $\mathrm{kPa}$ & 1 \\
\hline Max suction & $\mathrm{kPa}$ & 400 \\
\hline
\end{tabular}

Data pada Tabel 5 adalah data tanah hasil penelitian dengan campuran $20 \%$ LuSi dan 80\% Tanah lempung Kertajaya [5]. Material model yang digunakan yaitu Mohr Coulomb.

Untuk nilai $S W C C$ yaitu menggunakan residual water $0,30 \mathrm{~m}^{2} / \mathrm{m}^{2}$ dan nilai minimum suction $1 \mathrm{kPa}$ dan nilai maksimum $400 \mathrm{kPa}$. Parameter data tanah timbunan untuk pemodelan analisa numerik stabilitas tanggul yaitu data Berat volume kering $\left(\gamma_{\mathrm{t}}\right)$, kohesi (c), sudut geser $(\varnothing)$ serta parameter untuk suction.

\section{Hasil dan Pembahasan}

\subsection{Pemodelan Tanggul dengan Program Analisa Numerik}

Pada pemodelan tanggul bertujuan untuk mengetahui pengaruh nilai suction terhadap perubahan muka air tanah pada analisa numerik kestabilan, rembesan, dan penurunan segera tanggul penahan lumpur.

Pemodelan analisa numerik menggunakan muka air tanah kedalaman $0 \mathrm{~m}$ dan $-30 \mathrm{~m}$ dengan tujuan mengetahui fluktuasi pada muka air tanah terendah yaitu $-30 \mathrm{~m}$ dan muka air tanah tertinggi yaitu $0 \mathrm{~m}$.

Tabel 5. Data Tanah Timbunan untuk Pemodelan Analisa Numerik Stabilitas

\begin{tabular}{lccc} 
Parameter & Satuan & $\begin{array}{c}\text { Konsentrasi } \\
(\%)\end{array}$ & Keterangan \\
\hline BASIC & $\circ$ & 5,76 & Sesuai data \\
$\varnothing$ & $\mathrm{Kg} / \mathrm{cm}^{2}$ & 0,395 & sekunder \\
$c$ & $\mathrm{kN} / \mathrm{m}^{3}$ & 14,99 & \\
$\gamma_{\mathrm{t}}$ & & Mohr- & \\
Material & & Coulomb & Korelasi \\
Model & - & Clay W/C & Korelasi \\
Vol. WC & & Function & \\
Fn & & 30 & \\
Residual & & & \\
Water & & & \\
Content & & &
\end{tabular}

1. Pemodelan Variasi Muka Air Tanah $0 \mathrm{~m}$ dan $-30 \mathrm{~m}$ (Campuran Lusi Dan Tanah Lempung, Kertajaya Indah)

Pemodelan tanggul ini bertujuan untuk mengetahui pengaruh perubahan muka air tanah pada variasi muka air tanah (M.A.T) 0 meter dan -30 meter sebagai akibat perubahan musim terhadap kestabilan tanggul. Salah satu geometri tanggul yang dimodelkan dengan program bantu analisa numerik untuk rembesan dan analisa numerik untuk stabilitas tanggul dengan tinggi tanggul 5 meter, lebar tanggul 20 meter, dan kemiringan 1:1 seperti pada Gambar 3.

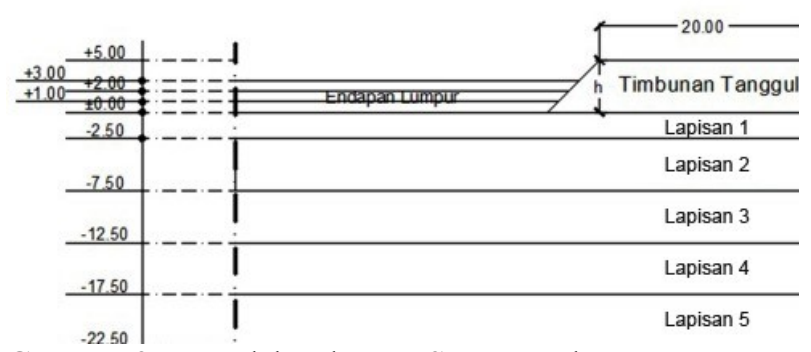

Gambar 3. Pemodelan dengan Suction pada Campuran Optimum LuSi dan tanah lempung (M.A.T $0 \mathrm{~m}$ dan $-30 \mathrm{~m}$ )

Variasi pemodelan muka air tanah dengan menggunakan konfigurasi geometri kemiringan seperti pada Tabel 6 yaitu $1: 1,1: 1,5$ dan $1: 2$ serta variasi ketinggian tanggul yaitu variasi ketinggian tanggul 3 meter, 5 meter, dan 7 meter 
pada muka air tanah (M.A.T) $0 \mathrm{~m}$. Geometri lapisan tanah bawah tanggul dengan kedalaman $-30 \mathrm{~m}$ yang terdapat 6 lapisan tanah. Dalam perhitungan ini model material yang digunakan adalah model Mohr Coulomb. Dari program analisa numerik untuk stabilitas didapatkan nilai faktor keamanan paling rendah yaitu pada ketinggian tanggul 7 meter dan kemiringan 1:1 dengan variasi M.A.T 0 meter yaitu sebesar 1,774 (Tabel 6). Ketinggian 7 meter dianggap paling kritis dikarenakan pada ketinggian tanggul $7 \mathrm{~m}$ lebih curam daripada hasil yang lain dipengaruhi pula oleh faktor slip surface yang diinputkan dalam analisa numerik.

Pada pemodelan tersebut ditentukan titik entry dan exit untuk mengetahui hasil dari slip surface pada timbunan tanggul. Hal tersebut merupakan tahapan akhir dari pemodelan untuk mengetahui nilai faktor keamanan pada timbunan tanggul.

Elevasi muka air tanah sangat berpengaruh terhadap angka keamanan (SF) lereng. Makin tinggi elevasi muka air tanah, slip surface yang terjadi makin pendek, maka angka keamanannya akan makin menurun [4].

Tabel 6. Hasil Pemodelan untuk Campuran LuSi dan Tanah Lempung M.A.T 0 Meter

\begin{tabular}{cccc}
\hline No & $\begin{array}{c}\text { Variasi } \\
\text { Ketinggian }\end{array}$ & $\begin{array}{c}\text { Variasi } \\
\text { Kemiringan }\end{array}$ & $\begin{array}{c}\text { Hasil } \\
\text { Faktor } \\
\text { Keamanan(SF) }\end{array}$ \\
\hline 1 & 3 & $1: 1$ & 2,709 \\
& 3 & $1: 1,5$ & 2,999 \\
& 3 & $1: 2$ & 3,44 \\
& 5 & $1: 1$ & 2,218 \\
& 5 & $1: 1,5$ & 2,51 \\
& 5 & $1: 2$ & 2,73 \\
& 7 & $1: 1$ & 1,774 \\
& 7 & $1: 1,5$ & 1,93 \\
& 7 & $1: 2$ & 2,243 \\
\hline
\end{tabular}

Pada Gambar 4 memperlihatkan bahwa semakin dekat kedalaman muka air tanah ke permukaan tanggul, faktor keamanan yang diperoleh semakin rendah. Semakin jauh lokasi tanah dari muka air tanah maka nilai suction semakin besar, sebaliknya semakin dekat lokasi tanah dengan muka air tanah maka nilai suction semakin kecil. Kondisi tersebut disebabkan oleh infiltrasi air hujan yang menyebabkan permukaan tanah menjadi jenuh air. Sebagai akibatnya akan meningkatkan kedalaman zona pembasahan (wetting zone) dan pengurangan suction atau peningkatan tekanan air pori [1]. Hal tersebut menunjukkan bahwa pengaruh muka air tanah juga perlu didukung dengan pengaruh nilai suction.
Pengaruh nilai suction pada $S W C C$ pemodelan tanggul mempengaruhi nilai angka keamanan pada tanggul. Pengaruh matric suction juga mempengaruhi tegangan geser tanah. Peningkatan tegangan geser tanah membuat tanggul dalam kondisi aman, jika terjadi berkurangnya tegangan geser tanah akibat berkurangnya matric suction tanah dapat menyebabkan kelongsoran (sliding) yang membuat tanggul dalam kondisi tidak aman [1].

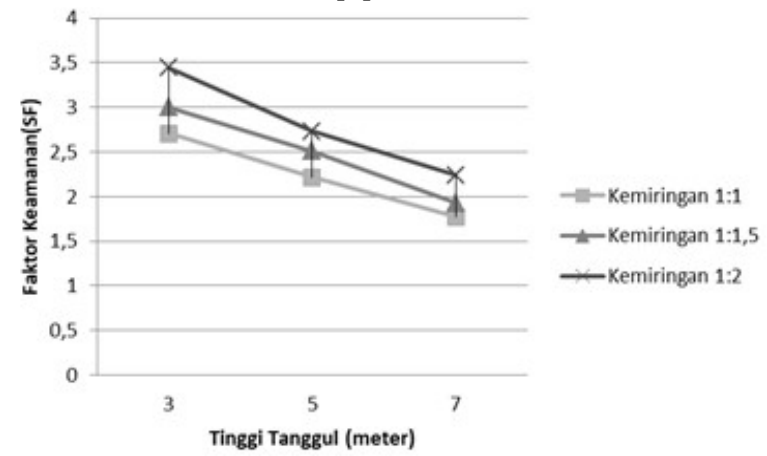

Gambar 4. Hubungan antara Ketinggian Tanggul dengan Faktor Keamanan

Tabel 7. Hasil Pemodelan untuk Campuran LuSi dan Tanah Lempung M.A.T -30 Meter

\begin{tabular}{cccc}
\hline No & $\begin{array}{r}\text { Variasi } \\
\text { Ketinggian }\end{array}$ & $\begin{array}{r}\text { Variasi } \\
\text { Kemiringan }\end{array}$ & $\begin{array}{c}\text { Hasil } \\
\text { Faktor } \\
\text { Keamanan(SF) }\end{array}$ \\
\hline 1 & 3 & $1: 1$ & 3,726 \\
& 3 & $1: 1,5$ & 4,207 \\
2 & 3 & $1: 2$ & 4,699 \\
& 5 & $1: 1$ & 3,142 \\
3 & 5 & $1: 1,5$ & 3,615 \\
& 5 & $1: 2$ & 4,015 \\
& 7 & $1: 1$ & 2,495 \\
& 7 & $1: 1,5$ & 2,71 \\
& 7 & $1: 2$ & 3,203 \\
\hline
\end{tabular}

Hasil pemodelan tanggul pada muka air tanah (M.A.T) 0 $\mathrm{m}$ pada Tabel 7 menjelaskan bahwa didapatkan kondisi semakin tinggi timbunan maka rentang angka keamanan 1,7 sampai 2,2 dan semakin besar kemiringan timbunan maka rentang angka keamanan yaitu $\mathrm{SF} \geq 2,2-3,4$. Pada ketinggian tanggul 7 meter dan kemiringan 1:1 nilai faktor keamanan yaitu 2,495 .

Hasil pemodelan tanggul pada muka air tanah (M.A.T) $30 \mathrm{~m}$ dengan variasi ketinggian yaitu $3 \mathrm{~m}, 5 \mathrm{~m}$, dan $7 \mathrm{~m}$ dan kemiringan 1:1, 1:1,5 dan 1:2 didapatkan kondisi bahwa semakin tinggi timbunan maka rentang angka keamanan antara 2,4 - 3,2 dan semakin besar kemiringan timbunan maka rentang angka keamanan antara 2,7 - 4,6. 
Hasil pemodelan menunjukkan bahwa semakin rendah muka air tanah pada $-30 \mathrm{~m}$, maka nilai faktor keamanan mengalami peningkatan dan menyebabkan tanggul dalam kondisi aman. Hal tersebut dikarenakan nilai suction memberikan nilai besar yang membuat tegangan geser tanah menjadi lebih besar.

Hasil analisis stabilitas lereng tanggul pada kondisi muka air tanah -30 meter ditunjukkan dengan grafik hubungan antara ketinggian tanggul dengan faktor keamanan pada Gambar 5.

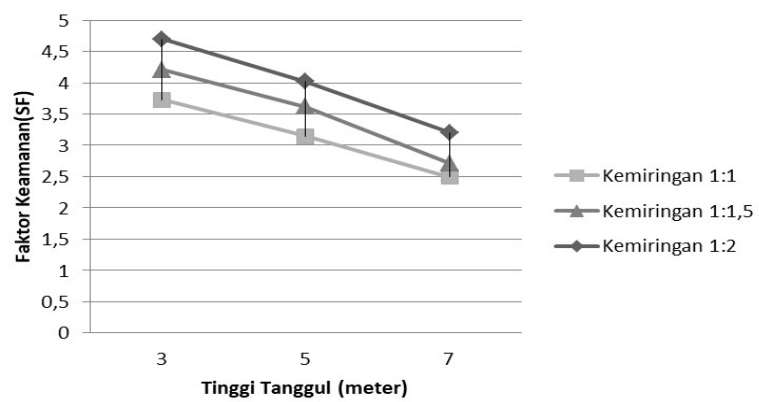

Gambar 5. Hubungan antara Ketinggian Tanggul dengan Faktor Keamanan

2. Pemodelan Variasi Endapan Lumpur (Campuran LuSi dan Tanah Lempung, Kertajaya Indah)

Geometri pemodelan endapan lumpur (Gambar 5) menunjukkan kondisi muka air tanah yaitu $0 \mathrm{~m}$ dengan variasi tinggi endapan lumpur $1 \mathrm{~m}, 2 \mathrm{~m}$, dan $3 \mathrm{~m}$. Gambar 6 menunjukkan geometri pemodelan pada kondisi ketinggian tanggul 7 meter dengan kondisi endapan lumpur 1 meter dan kemiringan tanggul 1:1.

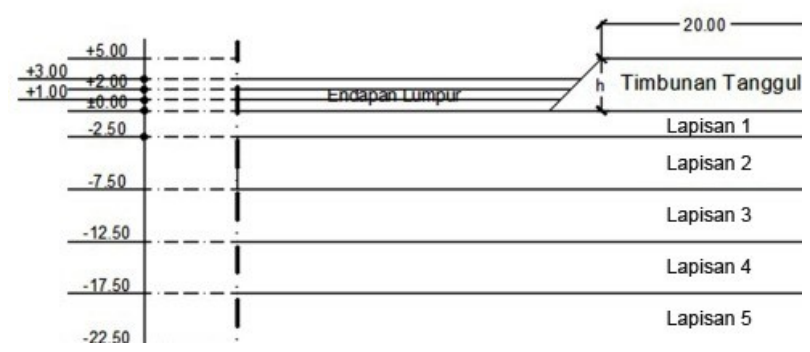

Gambar 6. Geometri Pemodelan Endapan Lumpur

Tabel 8 menunjukkan variasi konfigurasi geometri tanggul ketinggian tanggul $3 \mathrm{~m}, 5 \mathrm{~m}$, dan $7 \mathrm{~m}$ dengan kemiringan yang sama yaitu 1:1 dan muka air tanah yang sama yaitu M.A.T $0 \mathrm{~m}$ pada variasi tebal endapan lumpur $1 \mathrm{~m}, 2$ $\mathrm{m}$, dan $3 \mathrm{~m}$. Kesimpulan dari pemodelan tersebut adalah semakin tinggi endapan lumpur semakin besar nilai angka keamanan dan sebaliknya semakin rendah endapan lumpur, maka semakin kecil angka keamanan.

Pada pemodelan untuk endapan LuSi didapatkan hasil berupa 3 kondisi yaitu kondisi pertama, pada ketinggian endapan LuSi $1 \mathrm{~m}$ dengan semakin tinggi timbunan maka rentang angka keamanan antara 1,8-3,5. Kondisi kedua, pada tinggi endapan LuSi $2 \mathrm{~m}$ dengan semakin tinggi timbunan maka rentang angka keamanan antara 2,0- 4,7. Kondisi ketiga, pada endapan LuSi 3 m dapat dinyatakan bahwa semakin tinggi timbunan maka rentang angka keamanan antara 2,5-7,4.

Tabel 8. Hasil Pemodelan untuk Campuran LuSi dan Tanah Lempung untuk Endapan Lumpur

\begin{tabular}{cccc}
\hline No & $\begin{array}{r}\text { Variasi } \\
\text { Ketinggian }\end{array}$ & $\begin{array}{c}\text { Endapan } \\
\text { Lumpur }\end{array}$ & $\begin{array}{c}\text { Hasil } \\
\text { Faktor } \\
\text { Keamanan(SF) }\end{array}$ \\
\hline 1 & 3 & 1 & 3,512 \\
& 3 & 2 & 4,69 \\
2 & 3 & 3 & 7,476 \\
& 5 & 1 & 2,432 \\
3 & 5 & 2 & 2,591 \\
& 5 & 3 & 3,335 \\
& 7 & 1 & 1,878 \\
& 7 & 2 & 2,041 \\
& 7 & 3 & 2,51 \\
\hline
\end{tabular}

Pada Gambar 7 menunjukkan salah satu hasil Analisa numerik dengan ketinggian tanggul 7 m menunjukkan nilai angka keamanan yaitu 1,878 (Tabel 8) dengan kemiringan tanggul 1:1.

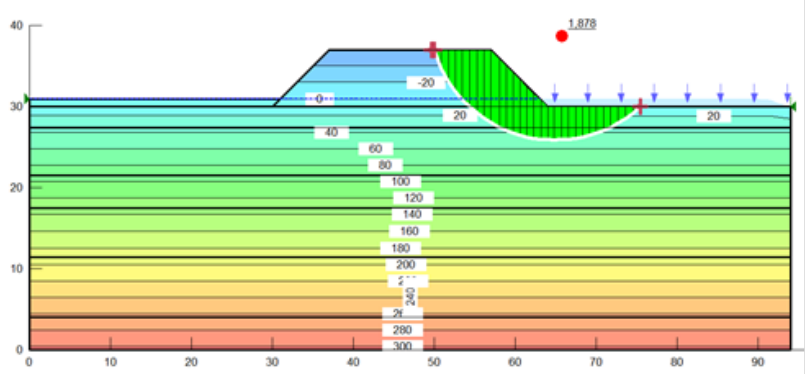

Gambar 7. Hasil Analisa Numerik terhadap Pemodelan Variasi Endapan Lumpur

Hasil dari analisa numerik yang direpresentasikan pada grafik hubungan antara ketinggian tanggul dengan faktor keamanan pada Gambar 8 menunjukkan bahwa semakin tinggi tanggul maka rentang angka keamanan cenderung menurun. 


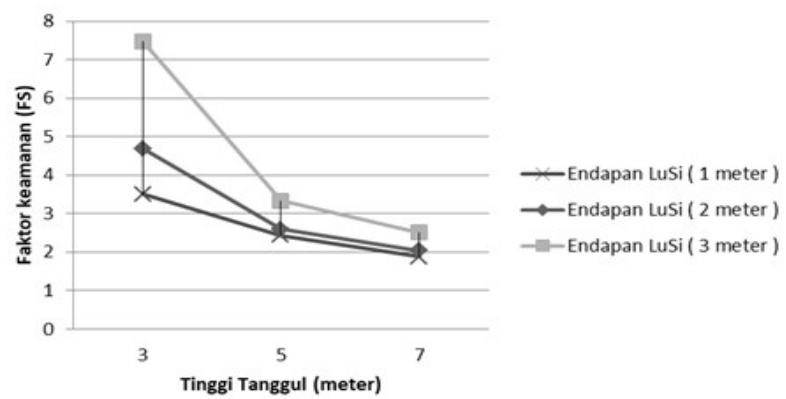

Gambar 8. Hubungan antara Ketinggian Tanggul dengan Faktor Keamanan

\section{Pengaruh Nilai Suction terhadap Faktor Keamanan Tanggul}

Pada pembahasan pengaruh nilai suction terhadap faktor keamanan tanggul bertujuan untuk mencari perhitungan faktor keamanan dengan pengaruh nilai suction dan pehitungan tanpa nilai suction dengan menggunakan analisa numerik.

Hasil faktor keamanan pada tanggul dengan 2 jenis program bantu geoteknik yang berbeda, dapat dilihat terdapat perbedaan hasil diantara keduanya yaitu hasil angka keamanan dengan analisa numerik untuk stabilitas menghasilkan angka keamanan yang lebih besar dibandingkan menggunakan analisa numerik untuk penurunan segera.

Pada hasil pemodelan diketahui bahwa adanya pengaruh nilai suction terhadap peningkatan faktor keamanan tanggul. Pemodelan dengan ketinggian 7 meter menggunakan program analisa numerik untuk stabilitas menghasilkan rentang angka keamanan (1,7-2).

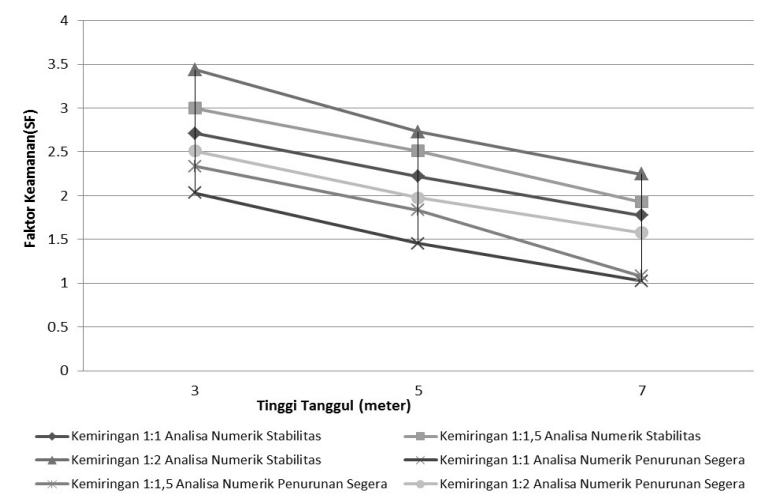

Gambar 9. Hubungan Antara Ketinggian Tanggul Dengan Faktor Keamanan Analisa Numerik Stabilitas dan Analisa Numerik Untuk Penurunan Segera

Berbeda dengan tanpa menggunakan nilai suction dengan analisa numerik untuk penurunan segera menunjukkan rentang angka keamanan (1-1,5). Hubungan ketinggian tanggul dengan nilai keamanan (Gambar 9) menunjukkan kesimpulan semakin tinggi tanggul maka penurunan angka keamanan semakin tinggi pula.

Hasil pemodelan pada Tabel 9 menunjukkan bahwa adanya perbedaan hasil nilai faktor keamanan yang dipengaruhi oleh analisa numerik untuk penurunan segera tidak memasukkan nilai suction pada timbunan tanggul sedangkan analisa numerik stabilitas menggunakan nilai suction pada parameter pemodelan tanggul.

Berdasarkan Tabel 9 dapat disimpulkan penting untuk memasukkan pengaruh nilai suction. Besar kecilnya nilai suction sangat menentukkan pada kelakuan baik fisik maupun mekanik dari tanah. Perubahan fisik yang mungkin terjadi pada tanah akibat turun naiknya hisapan antara lain adalah perubahan angka pori, kadar air dan derajat kejenuhan dari tanah, dari kondisi tanah cair sampai tanah mengalami kering dan keretakan. Perubahan mekanik tanah akibat pengaruh nilai suction adalah naik turunnya tegangan geser dan sudut geser dalam dari tanah. Akibat dari perubahanperubahan yang yang terjadi pada tegangan geser tanah maka kemampuan daya dukung tanah pun akan berubah, dari kondisi paling kuat sampai tanah mengalami keruntuhan [1]. Dalam hal ini, penting untuk memasukkan parameter nilai suction untuk mengetahui kestabilan pada tanggul.

Tabel 9. Hasil Pemodelan Program Bantu Analisa Numerik Untuk Stabilitas dan Rembesan

\begin{tabular}{|c|c|c|c|c|}
\hline No & $\begin{array}{c}\text { Variasi } \\
\text { Ketinggian }\end{array}$ & $\begin{array}{c}\text { Variasi } \\
\text { Kemiringan }\end{array}$ & $\begin{array}{c}\text { Analisa } \\
\text { Numerik } \\
\text { Stabilitas } \\
\text { Faktor } \\
\text { Keamanan } \\
\text { (SF) }\end{array}$ & $\begin{array}{c}\text { Analisa } \\
\text { Numerik } \\
\text { Penurunan } \\
\text { Segera } \\
\text { Faktor } \\
\text { Keamanan } \\
\text { (SF) }\end{array}$ \\
\hline \multirow[t]{3}{*}{1} & 3 & $1: 1$ & 2,709 & 2,03 \\
\hline & 3 & $1: 1,5$ & 2,999 & 2,334 \\
\hline & 3 & $1: 2$ & 3,44 & 2,512 \\
\hline \multirow[t]{3}{*}{2} & 5 & $1: 1$ & 2,218 & 1,455 \\
\hline & 5 & $1: 1,5$ & 2,51 & 1,833 \\
\hline & 5 & $1: 2$ & 2,73 & 1,974 \\
\hline \multirow[t]{3}{*}{3} & 7 & $1: 1$ & 1,774 & 1,025 \\
\hline & 7 & $1: 1,5$ & 1,93 & 1,082 \\
\hline & 7 & $1: 2$ & 2,243 & 1,557 \\
\hline
\end{tabular}

\subsection{Penurunan tanah Immediate Settlement (Penurunan Segera)}

Geometri simulasi ini memodelkan penurunan segera dengan kedalaman tanah dasar yaitu 30 meter dan lebar tanggul 20 meter. Analisis stabilitas lereng dilakukan pada 2 (dua) kondisi yaitu pada kondisi tanpa aliran (undrained) dan pada kondisi ada aliran (drained). 
Pada pemodelan ini dilakukan dengan variasi geometri tanggul untuk ketinggian $3 \mathrm{~m}, 5 \mathrm{~m}$, dan $7 \mathrm{~m}$ serta kemirirngan 1:1, 1:1,5 dan 1:2 dengan muka air tanah yang sama yaitu M.A.T 0 meter. Pemodelan dengan analisa numerik untuk penurunan segera menggunakan data campuran optimum LuSi dan tanah lempung Kertajaya Indah.

Pemodelan analisa numerik untuk penurunan segera ini menggunakan beberapa konfigurasi geometri tanggul. Pemodelan didasarkan pada parameter data sekunder campuran optimum yaitu nilai kohesi (c) dan sudut geser dalam $(\varnothing)$ yang dimasukkan pada analisa numerik untuk penurunan segera.

Hasil yang didapatkan dari pemodelan analisa numerik untuk penurunan segera ditunjukkan pada Tabel 10. Hasil ini direpresentasikan melalui grafik hubungan antara ketinggian tanggul dengan nilai keamanan, di mana hasilnya menunjukkan bahwa semakin tinggi tanggul maka penurunan segera semakin besar pula.

Tabel 10. Hasil Pemodelan Analisa Numerik untuk Penurunan Segera

\begin{tabular}{cccc}
\hline No & $\begin{array}{c}\text { Variasi } \\
\text { Ketinggian }\end{array}$ & $\begin{array}{c}\text { Variasi } \\
\text { Kemiringan }\end{array}$ & $\begin{array}{c}\text { Hasil } \\
\mathrm{U}_{\mathrm{y}} \text { (meter) }\end{array}$ \\
\hline 1 & 3 & $1: 1$ & 0,02278 \\
& 3 & $1: 1,5$ & 0,02226 \\
2 & 3 & $1: 2$ & 0,02166 \\
& 5 & $1: 1$ & 0,05581 \\
& 5 & $1: 1,5$ & 0,05155 \\
& 5 & $1: 2$ & 0,04972 \\
& 7 & $1: 1$ & 0,10107 \\
& 7 & $1: 1,5$ & 0,09549 \\
& 7 & $1: 2$ & 0,08876 \\
\hline
\end{tabular}

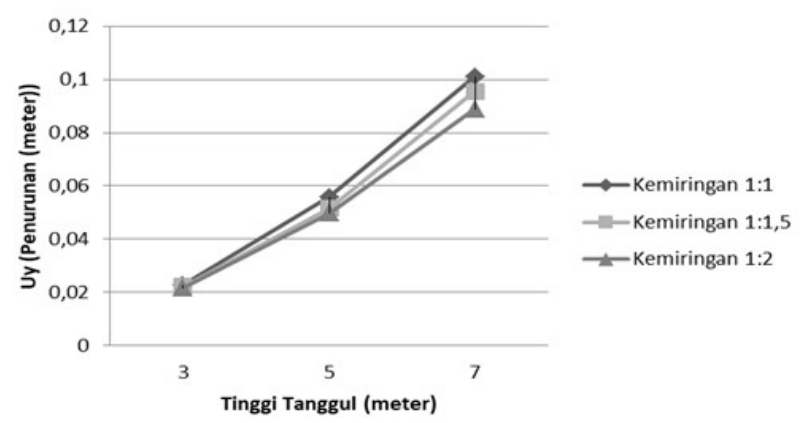

Gambar 10. Pemodelan Analisa Numerik Penurunan Segera

Hasil simulasi pemodelan dengan analisa numerik untuk penurunan segera (Immediate Settlement), didapatkan hasil bahwa timbunan yang menggunakan material campuran LuSi dan tanah lempung Kertajaya Indah menunjukkan nilai penurunan pada rentang antara $2 \mathrm{~cm}-10 \mathrm{~cm}$ per 200 hari.
Kondisi pemodelan direpresentasikan pada Gambar 10, dimana hasil penurunan segera (Immediate Settlement) yang terjadi pada kemiringan 1:1 jauh lebih besar dibandingkan dengan penurunan pada kemiringan 1:2. Semakin tinggi timbunan maka rentang penurunan antara $0,08876 \mathrm{~m}$ sampai 0,10107 $\mathrm{m}$ dan semakin besar kemiringan maka rentang penurunan segera sebesar $0,08876 \mathrm{~m}$ sampai $0,02166 \mathrm{~m}$.

\section{Simpulan}

Berdasarkan tujuan penelitian serta dari hasil pembahasan, maka dapat disimpulkan sebagai berikut:

1. Berdasarkan hasil validasi nilai suction maka dapat disimpulkan bahwa nilai suction dari hasil pemodelan telah memenuhi persyaratan sesuai kurva grafik $S W C C$. Proses validasi ini diperlukan sebagai persyaratan sebelum dilakukannya analisa kestabilan tanggul.

2. Pemodelan tanggul dilakukan berdasarkan data campuran optimum LuSi dan tanah lempung Kertajaya terhadap penerapan Soil-Water Characteristic Curve (SWCC) dengan dipengaruhi muka air tanah (M.A.T). Pada pemodelan muka air tanah (M.A.T) $0 \mathrm{~m}$ dengan variasi ketinggian yaitu $3 \mathrm{~m}, 5 \mathrm{~m}$, dan $7 \mathrm{~m}$ dan kemiringan 1:1, 1:1,5 dan 1:2 menunjukkan bahwa semakin tinggi timbunan menunjukkan rentang angka keamanan 1,7 sampai 2,2 dan semakin besar kemiringan timbunan maka rentang angka keamanan sebesar 2,2 - 3,4. Sedangkan, hasil pemodelan tanggul lainnya untuk muka air tanah (M.A.T) - $30 \mathrm{~m}$ dengan variasi ketinggian yaitu $3 \mathrm{~m}, 5 \mathrm{~m}$, dan $7 \mathrm{~m}$ dan kemiringan 1:1, 1:1,5 dan 1:2 didapatkan hasil bahwa semakin tinggi timbunan, maka rentang angka keamanan 2,4 - 3,2 dan semakin besar kemiringan timbunan maka rentang nilai angka keamanan yaitu antara 2,7 - 4,6.

3. Hasil simulasi pemodelan untuk analisa numerik penurunan segera (Immediate Settlement), didapatkan bahwa timbunan yang menggunakan material campuran LuSi dan tanah lempung Kertajaya Indah menunjukkan nilai penurunan yaitu rentang antara $2 \mathrm{~cm}-10 \mathrm{~cm}$ per 200 hari. Penurunan segera (Immediate Settlement) yang terjadi pada kemiringan 1:1 jauh lebih besar dibandingkan dengan penurunan kemiringan 1:2. Hasil analisa numerik untuk penurunan segera menunjukkan bahwa semakin tinggi timbunan, maka rentang penurunan $0,08876 \mathrm{~m}$ sampai 0,10107 $\mathrm{m}$ dan semakin besar kemiringan tanggul maka rentang penurunan segera sebesar $0,08876 \mathrm{~m}$ sampai $0,02166 \mathrm{~m}$.

\section{Daftar Pustaka}

[1] Indarto. "Peranan Variasi Kadar Air Terhadap 
Kestabilan Struktur Pondasi Dan Geoteknik." Seminar Nasional Aplikasi Teknologi Prasarana Wilayah: 1-8. Surabaya. 2009

[2] PU PR"Spesifikasi Pekerjaan Tanah". 2016.

[3] PUPR, PPLS. Monitoring Tanggul Uji Dengan Material Lumpur Sidoarjo Dan Borrow Area. Surakarta. 2018

[4] Sukmatirta K, dkk. "Analisis Perubahan Slip Surface Pada Lereng Akibat Pengaruh Elevasi Muka Air Tanah, Kemiringan, Dan Posisi Beban" Yogyakarta. 2005

[5] Utami, Gati Sri, dan Untung U. "Pada Ruas Jalan Kertajaya Indah Timur Surabaya.” (1): 1-8. Surabaya. 2015
[6] Yusof."The Soil Water Characteristic Curve of Unsaturated Tropical Residual Soil." Malaysia. 2013

[7] Zhang Z. Cheng, Q. Chen , X "Water Infiltration Underneath Single- Ring Permeameter and Hyddraulic Conductivity Determination. Journal of Hydrology, 393, 135-143. 2010.

Tabel 2. Data Tanah Dasar Untuk Program Rembesan

\begin{tabular}{|c|c|c|c|c|c|c|c|}
\hline Parameter & Satuan & Lapisan 1 & Lapisan 2 & Lapisan 3 & Lapisan 4 & Lapisan 5 & Lapisan 6 \\
\hline Kedalaman & $\mathrm{m}$ & $0-2,5$ & $2,5-8,5$ & $8,5-12,5$ & $12,5-18,5$ & $18,5-22,5$ & $22,5-30$ \\
\hline Tebal & $\mathrm{m}$ & 2,5 & 6 & 4 & 6 & 4 & 7,5 \\
\hline $\mathrm{c}$ & $\mathrm{Kg} / \mathrm{cm}^{2}$ & 0.09 & 0.10 & 0.07 & 0.10 & 0.10 & 0.2 \\
\hline$\varnothing$ & $\circ$ & - & 32 & - & 8 & - & 36 \\
\hline \multicolumn{8}{|l|}{ Satured X- } \\
\hline Conductity & $\mathrm{m} / \mathrm{sec}$ & $1.00 \mathrm{E}-08$ & 0.0001 & $1.00 \mathrm{E}-08$ & $1.00 \mathrm{E}-08$ & $1.00 \mathrm{E}-05$ & $1.00 \mathrm{E}-05$ \\
\hline Ky'Ratio & & 1 & 1 & 1 & 1 & 1 & 1 \\
\hline Kx' Ratio & $\circ$ & 0 & 0 & 0 & 0 & 0 & 0 \\
\hline$\gamma$ & $\mathrm{gr} / \mathrm{cm}^{3}$ & 1.51 & 1.7 & 1.42 & 1.34 & 1.42 & 1.80 \\
\hline Batas Cair & $\%$ & 26 & 19 & 27 & 42 & 28 & 32 \\
\hline Batas Plastis & $\%$ & 48 & 29 & 48 & 104 & 56 & 44 \\
\hline
\end{tabular}

